\title{
Bioprospecting from cultivable bacterial communities of marine sediment and invertebrates from the underexplored Ubatuba region of Brazil
}

\author{
Marcelo M. P. Tangerina ${ }^{1,2}$ (D) Hebelin Correa ${ }^{3} \cdot$ Brad Haltli $^{3,4}$. \\ Wagner Vilegas $^{1} \cdot$ Russell G. Kerr $^{3,4}$
}

Received: 14 March 2016 / Revised: 28 July 2016 / Accepted: 9 September 2016 / Published online: 19 September 2016

(C) Springer-Verlag Berlin Heidelberg 2016

\begin{abstract}
Shrimp fisheries along the Brazilian coast have significant environmental impact due to high by-catch rates (21 kg per kilogram of shrimp). Typically discarded, bycatch contains many invertebrates that may host a great variety of bacterial genera, some of which may produce bioactive natural products with biotechnological applications. Therefore, to utilize by-catch that is usually discarded we explored the biotechnological potential of culturable bacteria of two abundant by-catch invertebrate species, the snail Olivancillaria urceus and the sea star Luidia senegalensis. Sediment from the collection area was also investigated. Utilizing multiple isolation approaches, 134 isolates were obtained from the invertebrates and sediment. Small-subunit rRNA (16S) gene sequencing revealed that the isolates belonged to Proteobacteria, Firmicutes and
\end{abstract}

Communicated by Erko Stackebrandt.

Electronic supplementary material The online version of this article (doi:10.1007/s00203-016-1290-9) contains supplementary material, which is available to authorized users.

\section{Russell G. Kerr}

rkerr@upei.ca

1 Biosciences Institute, São Paulo State University - UNESP, Coastal Campus, Praça Infante Dom Henrique s/n, São Vicente, SP, P.O. Box 73601, 11380-972, Brazil

2 Chemistry Institute, São Paulo State University - UNESP, Araraquara Campus. Prof. Francisco Degni, 55, Araraquara, SP 14800-060, Brazil

3 Department of Chemistry, University of Prince Edward Island, 550 University Avenue, Charlottetown PE C1A 4P3, Canada

4 Department of Biomedical Sciences, Atlantic Veterinary College, University of Prince Edward Island, 550 University Avenue, Charlottetown PE C1A 4P3, Canada
Actinobacteria phyla and were distributed among 28 genera. Several genera known for their capacity to produce bioactive natural products (Micromonospora, Streptomyces, Serinicoccus and Verrucosispora) were retrieved from the invertebrate samples. To query the bacterial isolates for their ability to produce bioactive metabolites, all strains were fermented and fermentation extracts profiled by UP LC-HRMS and tested for antimicrobial activity. Four strains exhibited antimicrobial activity against methicillinresistant Staphylococcus aureus (MRSA) and Staphylococcus warneri.

Keywords Marine bacteria - Antimicrobial $16 \mathrm{~S}$ rDNA . Bacterial community $\cdot$ Luidia senegalensis · Olivancillaria urceus

\section{Introduction}

Microorganisms are widely recognized as one of the most important sources of bioactive natural products, many of which have found utility as treatments for a variety of diseases such as cancer, diabetes, hypercholesterolemia and infections causes by pathogens (Haygood et al. 1999; Spellberg et al. 2008; Hong et al. 2009; Fischbach and Walsh 2009). Antibiotic-resistant pathogens are an increasing health threat that makes the need to find new antibiotics particularly urgent (Kim et al. 2011). More than two-thirds of clinically used antibiotics are natural products or their semisynthetic derivatives. Despite this need for new bioactive compounds, natural product discovery has declined in the last few years, in part because of the rediscovery of known compounds and the difficulty in finding new antibiotics. Recent efforts to reinvigorate the antibiotic discovery via bioprospecting from underexplored ecological niches, 
unexplored bacterial taxa and even the genomes of wellstudied bacteria have yielded novel antimicrobial natural products, whereas new screening strategies have begun to circumvent the time-consuming problem of rediscovery (Fischbach and Walsh 2009).

Most natural product antibiotics have been discovered from bacteria within the order Actinomycetales (commonly referred to as actinomycetes), which are common soil inhabitants. Though more than $50 \%$ of the microbial antibiotics discovered so far originate from actinomycetes, two genera (Streptomyces and Micromonospora) account for most of these compounds (Wagman and Weinstein 1980; de Procópio et al. 2012). Recent explorations of marine environments have established marine bacteria, including marine actinomycetes, as a promising source of bioactive natural products (El Amraoui et al. 2014). This fact is exemplified by the discoveries of the potent anticancer agent salinosporamide $\mathrm{A}$ and the novel antibiotic abyssomicin C from the marine actinomycetes Salinospora tropica and Verrucosispora sp., respectively (Bister et al. 2004; Niewerth et al. 2014).

Despite the awareness of the biomedical potential of microbial natural products, the first natural product isolated from a microorganism discovered by Brazilian researchers was reported only in 2000 (Ióca et al. 2014). Among microbial natural products discovered in Brazil, only a small percentage $(9 \%)$ were discovered from bacteria (Ióca et al. 2014). Thus, bacteria from Brazilian habitats represent an underexplored resource.

Many marine invertebrates harbor a plethora of microorganisms, which also have the potential to produce novel bioactive compounds (Blunt et al. 2015). In some cases, symbiotic microorganisms are the true producers of metabolites first isolated from marine invertebrates (Mincer et al. 2002). One way to study marine organisms without generating extra alterations to the ecosystem is to investigate the unintentionally harvested marine organisms in fishing practices, commonly referred to as by-catch. By-catch fauna is defined as any organism that is not the intended target of the harvest, including fishes, turtles, crustaceans, mollusks and other organisms.

By-catch is a global problem, and the Food and Agriculture Organization (FAO) estimates that nearly 7 million tons of by-catch are discarded annually, an amount equivalent to $8 \%$ of the world's marine fisheries (Eayrs 2007). The bycatch associated with shrimp trawling in tropical waters is particularly egregious, accounting for $28 \%$ of all by-catch (Eayrs 2007). Bottom trawling fishing practices not only lead to low harvest selectivity, but also the destruction of the neritic biological diversity, particularly in the demersalbenthic layer. In spite of high by-catch rates, the marketable portion of the catch is sufficiently profitable that current fishing practices remain profitable. Continued use of nonselective fishing practices reduce biodiversity as the majority of discarded by-catch perishes, thereby disrupting the ecological balance of fished areas (Graça Lopes et al. 2002; Severino-rodrigues et al. 2004; Dos Santos 2007).

Two marine species commonly harvested as by-catch in bottom trawling fishing practices are the starfish Luidia senegalensis (Lamark, 1816) (Clarck and Downey 1992) and the gastropod Ollivancilaria urceus (Röding, 1798) (Röding 1798). To expand the breadth of Brazilian research in the area of bacterial natural product discovery and to add potential value to these by-catch organisms, we set out to study the culturable bacteria associated with $L$. senegalensis and $O$. urceus for their ability to produce bioactive natural products. A marine sediment sample collected in the same area as the invertebrates was also examined as sediments are an established source of natural product-producing marine bacteria (Sponga et al. 1999; Gontang et al. 2007; Dalisay et al. 2013). Due to their proven track record as a rich source of novel natural products, we focused our isolation methods on those selective for actinomycetes. Isolated bacteria were identified by $16 \mathrm{~S}$ rRNA gene sequencing, and fermentation extracts from selected isolates were screened for antimicrobial activity. The chemical composition of bioactive extracts was characterized by liquid chromatography-high-resolution mass spectrometry to identify compounds potentially responsible for the observed bioactivity.

\section{Materials and methods}

\section{Sample collection}

Collections were performed off the coast of Ubatuba, State of São Paulo, Brazil, by bottom trawling with a typical shrimp fishing net for $1 \mathrm{~h}$, on April 19, 2013, between the coordinates $23^{\circ} 29^{\prime} 21^{\prime \prime} \mathrm{S} / 44^{\circ} 59^{\prime} 95^{\prime \prime} \mathrm{E}$ and $23^{\circ} 33^{\prime} 01^{\prime \prime} \mathrm{S} / 45^{\circ} 00^{\prime} 54^{\prime \prime} \mathrm{E}$ at depths of $15-20 \mathrm{~m}$. After $1 \mathrm{~h}$ of trawling, by-catch specimens were collected and stored on ice until the fishing vessel returned to port $(\sim 3 \mathrm{~h})$. On shore, the specimens were separated by species and then stored at $-20{ }^{\circ} \mathrm{C}$ for 10 days until analysis. The sediment sample was collected at the end of the trawl $\left(23^{\circ} 33^{\prime} 01^{\prime \prime} \mathrm{S} / 45^{\circ} 00^{\prime} 54^{\prime \prime} \mathrm{E}\right)$ using a van Veen grab sampler deployed from the fishing vessel. The sediment sample was kept wet with sea water and stored on ice until arrival in the laboratory ( $24 \mathrm{~h}$ post-collection). In the laboratory, it was kept refrigerated at $4{ }^{\circ} \mathrm{C}$ for 10 days until processing. All samples were transported to Canada for processing. Invertebrate samples were transported frozen and the sediment sample in cold packs. 


\section{Isolation of bacteria}

For the isolation of bacteria, four different pretreatments specific to each type of sample were performed. When seawater was needed, seawater collected from the northern coast of Prince Edward Island, Canada, was filtered over a $0.45-\mu \mathrm{m}$ cellulose nitrate membrane and autoclaved. Serial dilutions were prepared using sterile sea water. Isolation plates were incubated at $28^{\circ} \mathrm{C}$ for a period of 10 days.

1. Dry-stamp method (dry sediment) (Mincer et al. 2002). A portion $(5 \mathrm{~g})$ of wet sediment was dried aseptically in a sterile petri dish $\left(24 \mathrm{~h}, 37^{\circ} \mathrm{C}\right)$ and ground lightly with a sterile mortar and pestle. An autoclaved foam plug (diameter $10 \mathrm{~mm}$ ) was pressed into the ground sediment, and excess sediment was dislodged from the plug by gently tapping the edge of the plug. Agar plates were inoculated by stamping the foam plug on the surface of the plate in a circular fashion, resulting in a serial dilution effect. Three plates each of media 1-5 were inoculated in this fashion.

2. Dispersal and differential centrifugation technique (DDC-wet sediment) (Hopkins et al. 1991). Five grams of wet sediment were ground with a sterile mortar and pestle in $10.0 \mathrm{~mL}$ of $0.1 \%(\mathrm{w} / \mathrm{v})$ sodium cholate solution. The ground sediment was aseptically transferred to a 50-mL centrifuge tube, and an additional $10 \mathrm{~mL}$ of $0.1 \%(\mathrm{w} / \mathrm{v})$ sodium cholate solution was added along with 30 sterile glass beads (4 mm diameter). The tube was shaken on its side at $60 \mathrm{rpm}$ at $5{ }^{\circ} \mathrm{C}$ for $2 \mathrm{~h}$. The mixture was centrifuged at $500 \mathrm{~g}$ for $2 \mathrm{~min}$ and the supernatant saved (DDC1). The precipitate was suspended in $10 \mathrm{~mL}$ of $50 \mathrm{mM}$ Tris-HCl buffer ( $\mathrm{pH} 8.0$ ) and stirred for $1 \mathrm{~h}$ at $5{ }^{\circ} \mathrm{C}$. The mixture was then centrifuged at $500 \mathrm{~g}$ for $1 \mathrm{~min}$. The supernatant was combined with DDC1. The pellet was suspended in $20 \mathrm{~mL}$ sodium cholate solution and sonicated in a Misonix Sonicator 3000 (New York, USA) at low power for 1 min. Following sonication, $10 \mathrm{~mL}$ of sodium cholate solution was added and the tube was shaken on its side at $60 \mathrm{rpm}$ for $1 \mathrm{~h}$ at $5{ }^{\circ} \mathrm{C}$. The mixture was centrifuged at $500 \mathrm{~g}$ for $1 \mathrm{~min}$ and the supernatant (DDC2) saved. The pellet was suspended in $10 \mathrm{~mL}$ of $50 \mathrm{mM}$ Tris- $\mathrm{HCl}$ buffer $(\mathrm{pH} 8.0)$ and shaken on its side at $60 \mathrm{rpm}$ for $1 \mathrm{~h}$ at $5{ }^{\circ} \mathrm{C}$. The mixture was centrifuged at $500 \mathrm{~g}$ for $1 \mathrm{~min}$ and the supernatant combined with DDC2. Cells present in DDC1 and DDC2 were collected by centrifugation $(12,000 \mathrm{~g}$, $4{ }^{\circ} \mathrm{C}$ ) and suspended in $10 \mathrm{~mL}$ of $50 \mathrm{mM}$ Tris- $\mathrm{HCl}$ buffer. For media $1-5,0.1 \mathrm{~mL}$ of undiluted and a $10^{-1}$ dilution of DDC1 and DDC2 were plated on five plates of each medium. For marine agar (MA), DDC1 and
DDC2 were serially diluted $\left(10^{-0}-10^{-7}\right)$, and $0.1 \mathrm{~mL}$ of each dilution was spread on three plates per dilution.

3. Heat-shock method (invertebrates) (Mincer et al. 2002). Invertebrates were thawed at room temperature, and in the case of $O$. urceus, shells were aseptically removed once thawed. From the starfish, two arms and the center disk of one specimen were homogenized. From $O$. urceus, two entire specimens were homogenized. Both invertebrates were mixed with $9 \mathrm{~mL}$ of sterile seawater and blended in a stainless steel autoclaved Waring blender. The mixture was heated for $60 \mathrm{~min}$ at $55^{\circ} \mathrm{C}$ to reduce the viability of asporogenous bacteria and then vortexed for $1 \mathrm{~min}$. The homogenates were serially diluted $\left(10^{-1}-10^{-8}\right)$ in sterile seawater, and $0.1 \mathrm{~mL}$ of each dilution was plated on agar plates. For media $1-5$, the $10^{-1}-10^{-3}$ dilutions were plated on each medium in triplicate. For MA, $0.1 \mathrm{~mL}$ of each dilution $\left(10^{-1}-10^{-8}\right)$ was plated in triplicate.

4. Phenol method (invertebrates) (Hayakawa et al. 2004). Phenol $(1.5 \% \mathrm{v} / \mathrm{v})$ was added to $10 \mathrm{~mL}$ of each invertebrate homogenate and shaken at $200 \mathrm{rpm}$ for $30 \mathrm{~min}$. Phenol-treated homogenates were diluted and plated as described for method 3.

Bacteria were also isolated from invertebrate homogenates without pretreatment. For these samples, a portion $(0.1 \mathrm{~mL})$ of serially diluted homogenates $\left(10^{-1}-10^{-8}\right)$ was plated on triplicate plates of MA.

\section{Culture media}

Five media were used, which had previously been developed for the isolation of Actinobacteria. The composition of the media is listed below.

Culture Medium 1 (Hayakawa and Nonomura 1987) (per L): humic acid, $1.0 \mathrm{~g}$ (solubilized in $10.0 \mathrm{~mL} \mathrm{NaOH}$ $0.2 \mathrm{~N}) ; \mathrm{Na}_{2} \mathrm{HPO}_{4}, 0.5 \mathrm{~g} ; \mathrm{KCl}, 1.71 \mathrm{~g} ; \mathrm{MgSO}_{4} \cdot 7 \mathrm{H}_{2} \mathrm{O}$, $0.05 \mathrm{~g} ; \mathrm{FeSO}_{4} \cdot 7 \mathrm{H}_{2} \mathrm{O}, 0.01 \mathrm{~g} ; \mathrm{CaCO}_{3}, 0.02 \mathrm{~g}$; vitamins (thiamine $\mathrm{HCl}$, riboflavin, niacin, pyridoxine $\mathrm{HCl}$, inositol, Capantothenate and $p$-aminobenzoic acid, $0.5 \mathrm{mg}$ each, and $0.25 \mathrm{mg}$ of biotin); agar, $18.0 \mathrm{~g}$; seawater, to $1.0 \mathrm{~L}$; $\mathrm{pH} 8.0$; vitamins were filter sterilized $(0.22 \mu \mathrm{m})$ and added to the medium after autoclaving. Culture Medium 2 (Rowbotham and Cross 1977) (per L): $\mathrm{KH}_{2} \mathrm{PO}_{4}, 0.466 \mathrm{~g} ; \mathrm{Na}_{2} \mathrm{HPO}_{4}$, $0.732 \mathrm{~g} ; \mathrm{KNO}_{3}, 0.10 \mathrm{~g} ; \mathrm{MgSO}_{4} \cdot 7 \mathrm{H}_{2} \mathrm{O}, 0.10 \mathrm{~g} ; \mathrm{CaCO}_{3}$, $0.02 \mathrm{~g}$; sodium propionate, $0.20 \mathrm{~g}$; $\mathrm{FeSO}_{4} \cdot 7 \mathrm{H}_{2} \mathrm{O}, 200 \mu \mathrm{g}$; $\mathrm{ZnSO}_{4} \cdot 7 \mathrm{H}_{2} \mathrm{O}, 180 \mu \mathrm{g} ; \mathrm{MnSO}_{4} \cdot \mathrm{H}_{2} \mathrm{O}, 20 \mu \mathrm{g}$; thiamine $4 \mathrm{mg}$; agar, $18.0 \mathrm{~g}$; seawater, to $1.0 \mathrm{~L}$; $\mathrm{pH}$ 8.0. Thiamine was filter sterilized $(0.22 \mu \mathrm{m})$ and added to the medium after autoclaving. Culture Medium 3 (Athalye et al. 1981) (per L): yeast extract, $10.0 \mathrm{~g}$; glucose, $10.0 \mathrm{~g}$; agar, $15.0 \mathrm{~g}$; seawater, to $1.0 \mathrm{~L}$; pH 8.0. Culture Medium 4 (Vicente et al. 2013): 
mannitol, $0.5 \mathrm{~g}$; peptone, $0.1 \mathrm{~g}$; agar, $18.0 \mathrm{~g}$; seawater, to $1.0 \mathrm{~L}$; novobiocin $(20 \mathrm{mg}$ ) was filter sterilized and added post-sterilization. Culture Medium 5 (Vicente et al. 2013) (per L): colloidal chitin, $0.5 \mathrm{~g}$; agar, $18.0 \mathrm{~g}$; seawater to 1.0 L. Marine Agar (Difco ${ }^{\mathrm{TM}}$ ) (MA) was prepared with deionized water according to the manufacturer's recommendations. Cycloheximide $(50 \mathrm{mg} / \mathrm{L})$ was added to media 1, 2, 4 , and 5 to suppress fungal growth (Williams and Davies 1965). Rifampicin $(5 \mathrm{mg} / \mathrm{L})$ and streptomycin $(15 \mathrm{mg} / \mathrm{L})$ were added to medium 3 to suppress the growth of fastgrowing Streptomyces and to favor the isolation of less frequently isolated Actinobacteria such as Actinoplanes (Dworkin et al. 2006). Novobiocin $(20 \mathrm{mg} / \mathrm{L})$ was added to media 4 and 5 to suppress the growth of non-actinomycetes (Qiu et al. 2008).

Emerging colonies were purified by serial subculturing on the same medium from which they were first observed. Following initial purification, isolates were transferred to MA culture medium and those exhibiting similar morphological characteristics from the same source were grouped and one of each group was selected for identification.

\section{Bacteria identification}

Bacteria were identified by sequencing of the small-subunit (16S) ribosomal RNA gene. To generate template DNA for PCR amplification, one colony of each axenic strain was suspended in 50- $\mu \mathrm{L}$ PCR grade DMSO (Sigma). PCR amplification of the 16S rRNA gene was conducted in $50 \mu \mathrm{L}$ volumes and consisted of the following: EconoTaq ${ }^{\circledR}$ PLUS GREEN 2X Master Mix $(25 \mu \mathrm{L})$ (Lucigen, Middleton, WI, USA), $0.5 \mu \mathrm{M}$ of the primers pA (5'-AGAGTTTGATCMTGGCTCAG) and $\mathrm{pH}$ (5'-AAGGAGGTGWTCCARCC) and genomic DNA ( $2.5 \mu \mathrm{L}$ of template in DMSO) (Edwards et al. 1989). Thermal cycling parameters consisted of initial denaturation at $94{ }^{\circ} \mathrm{C}$ for $2 \mathrm{~min}, 30$ cycles of $94{ }^{\circ} \mathrm{C}$ for $30 \mathrm{~s}, 60{ }^{\circ} \mathrm{C}$ for $30 \mathrm{~s}$ and $72{ }^{\circ} \mathrm{C}$ for $1.5 \mathrm{~min}$ followed by a final extension at $72{ }^{\circ} \mathrm{C}$ for $5 \mathrm{~min}$. A negative control, which lacked template DNA (DMSO only), was included in each set of PCRs. Amplification was evaluated by agarose gel electrophoresis.

Partial sequencing of 16S rDNA amplicons was performed by Eurofins MWG Operon (Huntsville, AL, USA) using the $16 \mathrm{~S} 936 \mathrm{R}$ primer (5'-GGGGTTATGCCTGAGCAGTTTG) (Duncan et al. 2014).

\section{Phylogenetic analysis of cultured bacteria}

Sequences were analyzed, edited and grouped into operational taxonomic units (OTUs) using the Contig Express application within the Vector NTI version 10.3 software package (Invitrogen, Carlsbad, CA, USA). The level of $16 \mathrm{~S}$ rDNA sequence identity which corresponds to genomic species demarcation based on a genome average nucleotide identity of $95-96 \%$ was recently determined to be $98.65 \%$ (Kim et al. 2014). This determination was based on nearly full-length $16 \mathrm{~S}$ rDNA sequences. As we obtained partial sequences approximately $600-800 \mathrm{bp}$ in length, a more conservative species-level 16S rDNA identity cutoff of $99 \%$ identity was used to define OTUs. To identify the closest relatives, sequences were compared to those in the NCBI database (http://www.ncbi.nlm.nih.gov/) using the Basic Local Alignment Search Tool (BLAST) (Altschul et al. 1990). Sequences were aligned using BioEdit version 7.2.5 with the ClustalW tool, and phylogenetic analysis of partial 16S rDNA sequences was conducted using the neighbor-joining algorithm (Saitou and Nei 1987) based on distances estimated by Kimura's two-parameter model using Molecular Evolutionary Genetics Analysis-MEGA version 6.0 (Tamura et al. 2013). Neighbor-joining (NJ) trees were prepared using default settings with complete deletion (Felsenstein 1985). The robustness of the resulting phylogeny was evaluated by bootstrap analysis of $\mathrm{NJ}$ data based on 1000 re-samplings (Felsenstein 1985).

\section{Bacteria cultivation and extraction}

Marine Broth $\left(\right.$ Difco $\left.^{\mathrm{TM}}\right)$ medium was prepared with ultrapure water according to the manufacturer's recommendations and dispensed $(7 \mathrm{~mL})$ into culture tubes $(150 \times 25 \mathrm{~mm})$ containing 3 glass beads $(4 \mathrm{~mm}$ dia) and sterilized by autoclaving $\left(121{ }^{\circ} \mathrm{C}\right.$ for $\left.30 \mathrm{~min}\right)$. Seed cultures were prepared by inoculating an axenic colony into a fresh tube and culturing for 3 days at room temperature $\left(22-25{ }^{\circ} \mathrm{C}\right)$ and $200 \mathrm{rpm}$. After this period, $1.0 \mathrm{~mL}$ of the broth was transferred to a new tube containing the same medium, which was fermented for one more day under the same conditions. A portion $(210 \mu \mathrm{L})$ of the second stage seed culture was used to inoculate duplicated culture tubes containing $7 \mathrm{~mL}$ of Marine Broth. Tubes were incubated at room temperature and $200 \mathrm{rpm}$ for 7 days. Fermentations were extracted twice with $10 \mathrm{~mL}$ ethyl acetate by rapid agitation $(200 \mathrm{rpm})$ at room temperature for $1 \mathrm{~h}$. Ethyl acetate extracts were washed with Milli-Q water to remove salts and then dried under air.

\section{Antimicrobial assays}

All microbroth dilution antimicrobial screening was carried out in 96-well plates in accordance with Clinical Laboratory Standards Institute testing standards (NCCLS, 2003) using the following pathogens: methicillin-resistant Staphylococcus aureus ATCC 33591 (MRSA), S. warneri ATCC 17917, vancomycin-resistant Enterococcus faecium EF379 (VRE), Pseudomonas aeruginosa ATCC 14210, Proteus vulgaris ATCC 12454, and Candida albicans ATCC 14035. 
Pathogens were cultured in $20 \mathrm{~mL}$ of CAMHB (cation adjusted Mueller-Hinton broth) (all bacteria) and SD (Sabouraud dextrose broth) (C.albicans). After growth overnight, the cell density of each culture was adjusted to $4.5 \times 10^{4}$ $\mathrm{CFU} / \mathrm{mL}$ by dilution into fresh media. Extracts were dissolved in sterile $20 \%$ DMSO (aq) and assayed at $100 \mu \mathrm{g} /$ $\mathrm{mL}$ with a final DMSO concentration of $2 \%$ DMSO (v/v; aq). Each plate contained three uninoculated positive controls (media + vehicle), three untreated negative controls (Media + vehicle + organism), and six wells containing a concentration range of a control antibiotic (vancomycin for MRSA, and S. warneri, rifampicin for VRE, gentamicin for $P$. aeruginosa, ciprofloxacin for $P$. vulgaris, nystatin for $C$. albicans). The optical density (OD) of the plate was recorded using a Thermo Scientific Varioskan Flash plate reader at $600 \mathrm{~nm}$ at time zero and then again after incubation of the plates for $22 \mathrm{~h}$ at $37{ }^{\circ} \mathrm{C}$. After subtracting the time zero $\mathrm{OD}_{600}$ from the final reading, the percentage of microorganism survival relative to vehicle control wells were calculated using the equation $100-100 \times\left(\mathrm{T}_{\text {final }}-\right.$ $\mathrm{T}_{\text {zero }}$ ) - Media Blank)/(Negative Control-MediaBlank).

\section{UPLC-HRMS analysis}

Extracts that showed antimicrobial activity were analyzed by ultrahigh-performance liquid chromatography-highresolution mass spectrometry (UPLC-HRMS) using an
ESI-LTQ Orbitrap Velos (Thermo Scientific ${ }^{\circledR}$ ) operating with a resolution of 30,000 and using a Core-Shell $100 \AA \mathrm{C} 18$ column (Phenomenex ${ }^{\circledR}$ Kinetex, $1.7 \mu \mathrm{m}$ $50 \times 2.1 \mathrm{~mm}$ ). A linear solvent gradient from $95 \%$ $\mathrm{H}_{2} \mathrm{O} / 0.1 \%$ formic acid (solvent A) and $5 \% \mathrm{CH}_{3} \mathrm{CN} / 0.1 \%$ formic acid (solvent $\mathrm{B}$ ) to $100 \%$ solvent $\mathrm{B}$ over $4.8 \mathrm{~min}$ followed by a hold for $3.2 \mathrm{~min}$ with a flow rate of $500 \mu \mathrm{L} /$ min. Eluent was detected by ESI-MS monitoring $\mathrm{m} / z, 190$ 2000 in positive mode, evaporative light scattering detector (ELSD; Sedex) and PDA (200-600 nm). All analyses were processed using Thermo Xcalibur 2.2 SP1.48 software. To putatively identify ions observed in UP LC-HRMS analyses, observed molecular weights of pseudomolecular ions were used to search the Antibase 2014 (Wiley-VCH) database. To avoid interference from media components, media blanks were analyzed using the same method and the ions observed subtracted from the sample files.

\section{Results}

\section{Bacteria isolation and identification}

A total of 230 isolates were picked from initial isolation plates inoculated with dilutions of the two invertebrate and single sediment sample. Initial dereplication of strains obtained from each sample was conducted on the basis

Table 1 Summary of isolates obtained from different samples using different pretreatments and isolation media. Numbers represent "number of isolates/number of genera"

\begin{tabular}{|c|c|c|c|c|c|c|c|c|c|c|c|c|c|c|c|c|c|c|c|c|c|c|c|}
\hline \multirow{2}{*}{$\begin{array}{l}\text { Sample } \\
\text { Culture media }\end{array}$} & \multicolumn{5}{|c|}{ Dry sediment $(41 / 10)$} & \multicolumn{6}{|c|}{ Wet sediment $(9 / 2)$} & \multicolumn{6}{|c|}{ Snail (31/12) } & \multicolumn{6}{|c|}{ Sea star $(53 / 20)$} \\
\hline & 1 & 2 & 3 & 4 & 5 & 1 & 2 & 3 & 4 & 5 & MA & 1 & 2 & 3 & 4 & 5 & MA & 1 & 2 & 3 & 4 & 5 & MA \\
\hline \multicolumn{24}{|l|}{ Actinobacteria } \\
\hline Untreated & - & - & - & - & - & - & - & - & - & - & - & - & - & - & - & - & $4 / 3$ & - & - & - & - & - & $14 / 7$ \\
\hline DDC & - & - & - & - & - & $0 / 0$ & $0 / 0$ & $0 / 0$ & $0 / 0$ & $0 / 0$ & $0 / 0$ & - & - & - & - & - & - & - & - & - & - & - & - \\
\hline Dry-stamp & $0 / 0$ & $5 / 5$ & $0 / 0$ & $1 / 1$ & $10 / 2$ & - & - & - & - & - & - & - & - & - & - & - & - & - & - & - & - & - & - \\
\hline Heat-shock & - & - & - & - & - & - & - & - & - & - & - & $1 / 1$ & $1 / 1$ & $0 / 0$ & $0 / 0$ & $1 / 1$ & - & $1 / 1$ & $2 / 2$ & $0 / 0$ & $3 / 1$ & $2 / 2$ & - \\
\hline Phenol & - & - & - & - & - & - & - & - & - & - & - & $0 / 0$ & $0 / 0$ & $0 / 0$ & $0 / 0$ & $0 / 0$ & - & $0 / 0$ & $0 / 0$ & $0 / 0$ & $1 / 1$ & $1 / 1$ & - \\
\hline \multicolumn{24}{|l|}{ Proteobacteria } \\
\hline Untreated & - & - & - & - & - & - & - & - & - & - & - & - & - & - & - & - & $6 / 2$ & - & - & - & - & - & $8 / 4$ \\
\hline $\mathrm{DDC}$ & - & - & - & - & - & $0 / 0$ & $0 / 0$ & $0 / 0$ & $2 / 1$ & $1 / 1$ & $6 / 2$ & - & - & - & - & - & - & - & - & - & - & - & - \\
\hline Dry-stamp & $2 / 2$ & $1 / 1$ & $0 / 0$ & $0 / 0$ & $0 / 0$ & - & - & - & - & - & - & - & - & - & - & - & - & - & - & - & - & - & - \\
\hline Heat-shock & - & - & - & - & - & - & - & - & - & - & - & $0 / 0$ & $0 / 0$ & $0 / 0$ & $0 / 0$ & $0 / 0$ & - & $0 / 0$ & $0 / 0$ & $0 / 0$ & $0 / 0$ & $0 / 0$ & - \\
\hline Phenol & - & - & - & - & - & - & - & - & - & - & - & $0 / 0$ & $0 / 0$ & $0 / 0$ & $0 / 0$ & $0 / 0$ & - & $0 / 0$ & $0 / 0$ & $0 / 0$ & $0 / 0$ & $0 / 0$ & - \\
\hline \multicolumn{24}{|l|}{ Firmicutes } \\
\hline Untreated & - & - & - & - & - & - & - & - & - & - & - & - & - & - & - & - & $5 / 3$ & - & - & - & - & - & $2 / 2$ \\
\hline DDC & - & - & - & - & - & $0 / 0$ & $0 / 0$ & $0 / 0$ & $0 / 0$ & $0 / 0$ & $0 / 0$ & - & - & - & - & - & - & - & - & - & - & - & - \\
\hline Dry-stamp & $6 / 2$ & $15 / 5$ & $0 / 0$ & $1 / 1$ & $0 / 0$ & - & - & - & - & - & - & - & - & - & - & - & - & - & - & - & - & - & - \\
\hline Heat-shock & - & - & - & - & - & - & - & - & - & - & - & $4 / 2$ & $5 / 3$ & $1 / 1$ & $0 / 0$ & $0 / 0$ & - & $5 / 3$ & $1 / 1$ & $2 / 1$ & $1 / 1$ & $2 / 2$ & - \\
\hline Phenol & - & - & - & - & - & - & - & - & - & - & - & $1 / 1$ & $2 / 1$ & $0 / 0$ & $0 / 0$ & $0 / 0$ & - & $4 / 3$ & $6 / 3$ & $0 / 0$ & $0 / 0$ & $1 / 1$ & - \\
\hline
\end{tabular}


of morphological characteristics (e.g., colony shape, size and color) and resulted in the selection of 134 strains for identification by partial 16S rRNA gene sequencing. The distribution of isolates between samples was as follows: sediment-50 isolates, $L$. senegalensis-53 isolates, $O$. urceus - 31 isolates. In total, 64 OTUs were obtained using a $99 \%$ sequence identity cutoff. Isolates were distributed among 28 genera belonging to the phyla Proteobacteria (8 OTUs), Actinobacteria (22 OTUs) and Firmicutes (34 OTUs) (Tables 1 and S1).

The wet sediment yielded the fewest isolates (9) and lowest number of genera with only Pseudoalteromonas (89 \%; 1 OTU) and Vibrio (11\%; 1 OTU) recovered from this sample (Tables 1 and S1). A substantially higher number of isolates, OTUs (41 isolates/18 OTUs) and a greater variety of genera were obtained from the dried sediment (Tables 1 and S1). The majority of isolates were Firmicutes (53\% of isolates/7 OTUs); Bacillus spp. constituted the majority of this group (81\%, 6 OTUs). Actinobacteria were the next most abundant group (40\% of isolates $/ 8$ OTUs). Five actinobacterial genera were obtained, with Micromonospora spp. accounting for $66 \%$ of isolates (5 OTUs). Other Actinobacteria obtained from dried sediment, which are notable due to their propensity to produce bioactive natural products, was a single Streptomyces isolate and two Verrucosispora isolates. The remaining isolates (7\%) were Proteobacteria belonging to the genera Wenxinia and Erythrobacter (1 OTU each). Among the marine invertebrates, the sea star L. senegalensis yielded the largest number of isolates and the greatest taxonomic variety, with 53 isolates and 28 OTUs distributed among 20 genera (Tables 1 and S1). Firmicutes and Actinobacteria accounted for the overwhelming majority of isolates from L. senegalensis (50 and $46 \%$ of isolates, respectively), while Proteobacteria (Pseudomonas and Psychrobacter) accounted for the remaining $4 \%$. Among the Firmicutes, Bacillus spp. were the most abundant (29\%) followed by seven other genera each accounting for $2-9 \%$ of isolates. The proportions of Actinobacteria isolates were more evenly distributed among 10 genera: Micromonospora (9\%), Kocuria (9\%), Streptomyces (6\%), Rhodococuccus (6 \%), Cellulosimicrobium (4\%), Dietzia (4\%), Arthrobacter (2\%), Microbacterium (2\%) and Serinicoccus (2\%). The snail O. urceus yielded 31 isolates belonging to 16 OTUS and 10 different genera (Tables 1 and S1). Firmicutes accounted for $61 \%$ of isolates, with Bacillus spp. constituting the

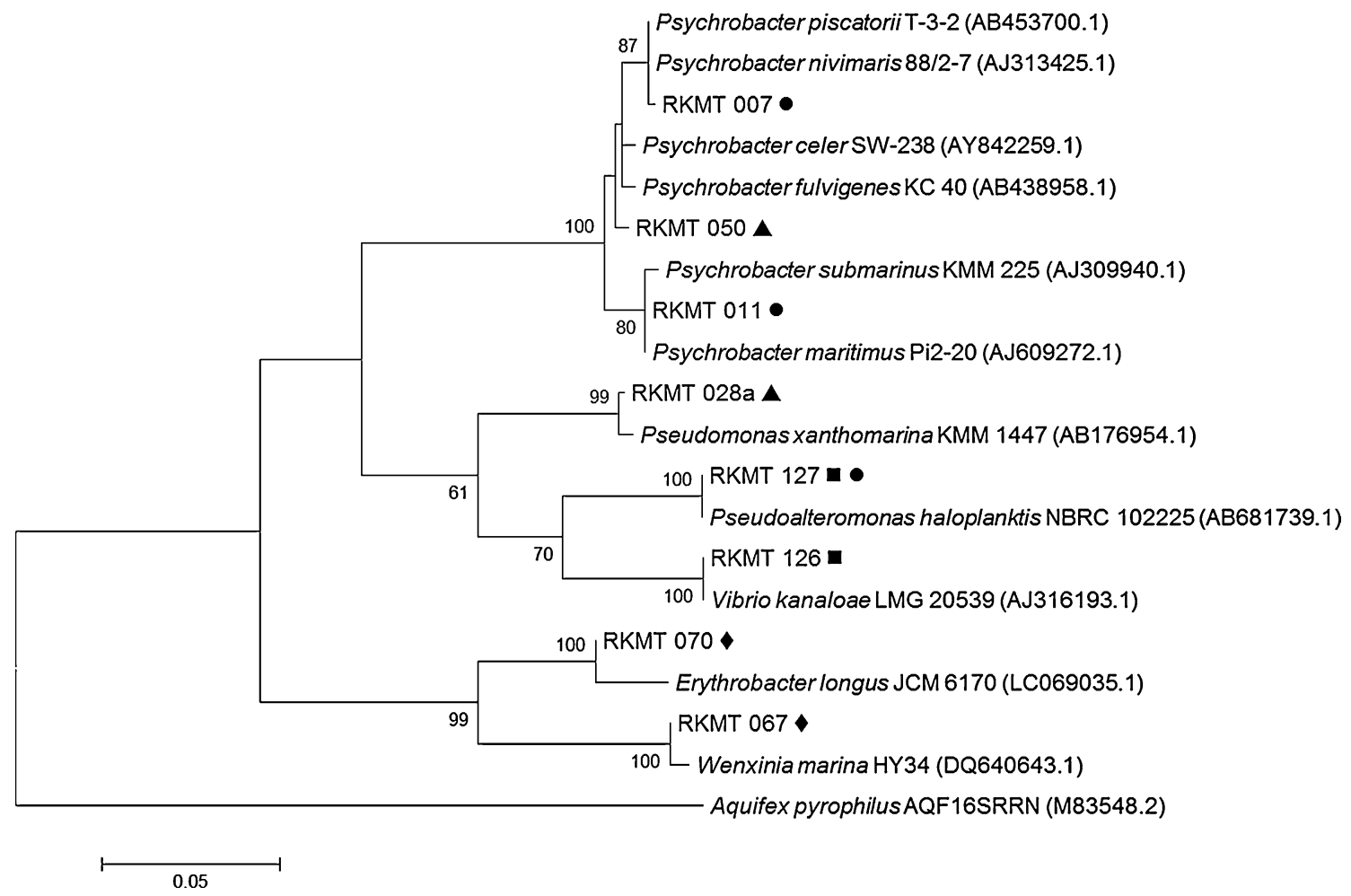

Fig. 1 Phylogenetic analysis of Proteobacteria isolates obtained from Brazilian sediment and the invertebrates Luidia senegalensis and Olivancillaria urceus. Prior to tree construction, sequences sharing $>99 \%$ sequence identity were grouped into OTUs and a single representative of each OTU was used in the phylogenetic analysis. The sources of isolates belonging to an OTU are indicated by sym- bols which follow the strain number: wet sediment-square; dry sediment-diamond; Luidia senegalensis—triangle; Olivancillaria urceus-circle. Neighbor-joining tree constructed using MEGA 6. The analysis considered 577 nucleotides. Bootstrap values greater than $50 \%$ are shown at the nodes and are based on 1000 iterations. The scale bar represents the number of base substitutions per site 
Fig. 2 Phylogenetic analysis of Firmicutes isolates obtained from Brazilian sediment and the invertebrates Luidia senegalensis and Olivancillaria urceus. Prior to tree construction, sequences sharing $>99 \%$ sequence identity were grouped into OTUs and a single representative of each OTU was used in the phylogenetic analysis. The sources of isolates belonging to an OTU are indicated by symbols which follow the strain number: wet sediment-square; dry sediment-diamond;

Luidia senegalensis-triangle; Olivancillaria urceuscircle. Neighbor-joining tree constructed using MEGA 6. The analysis considered 573 nucleotides. Bootstrap values greater than $50 \%$ are shown at the nodes and are based on 1000 iterations. The scale bar represents the number of base substitutions per site

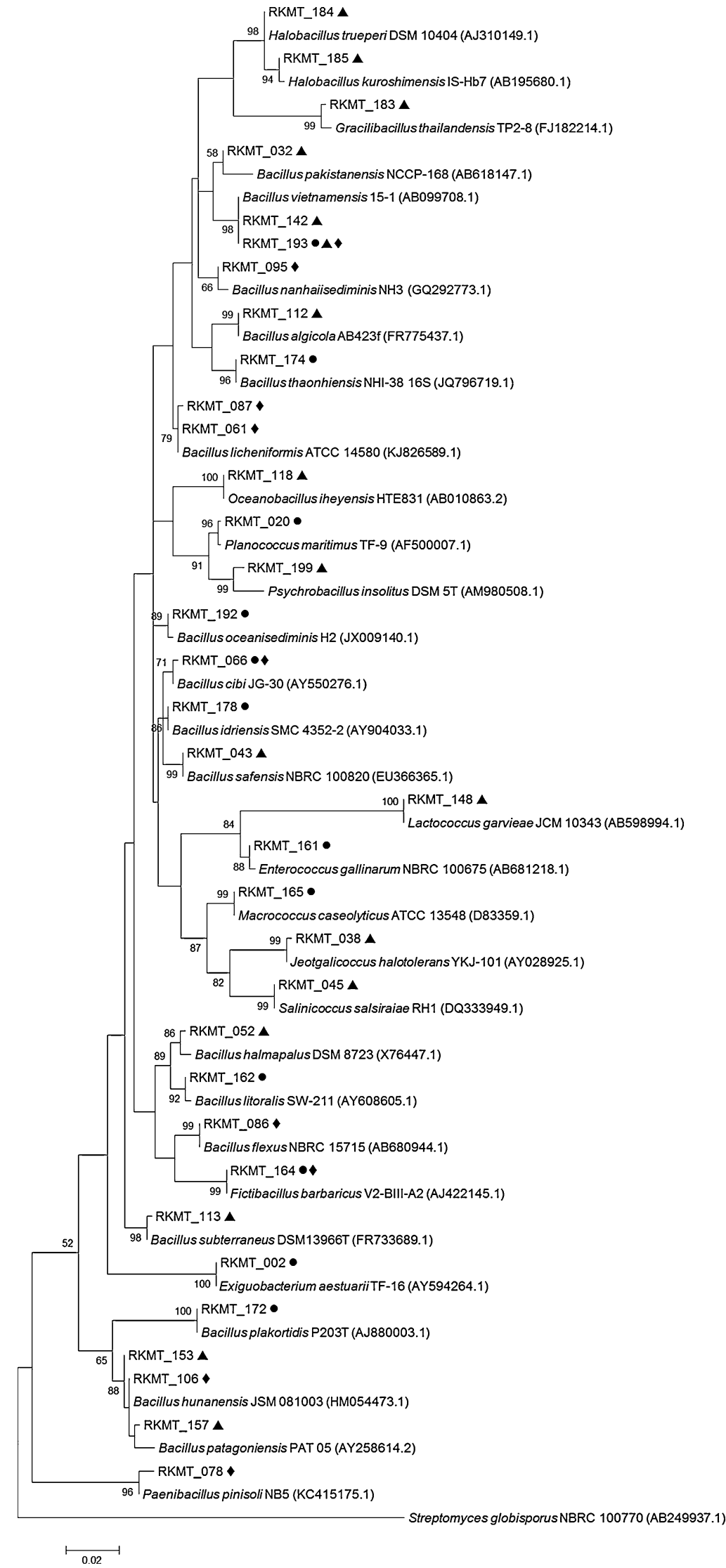




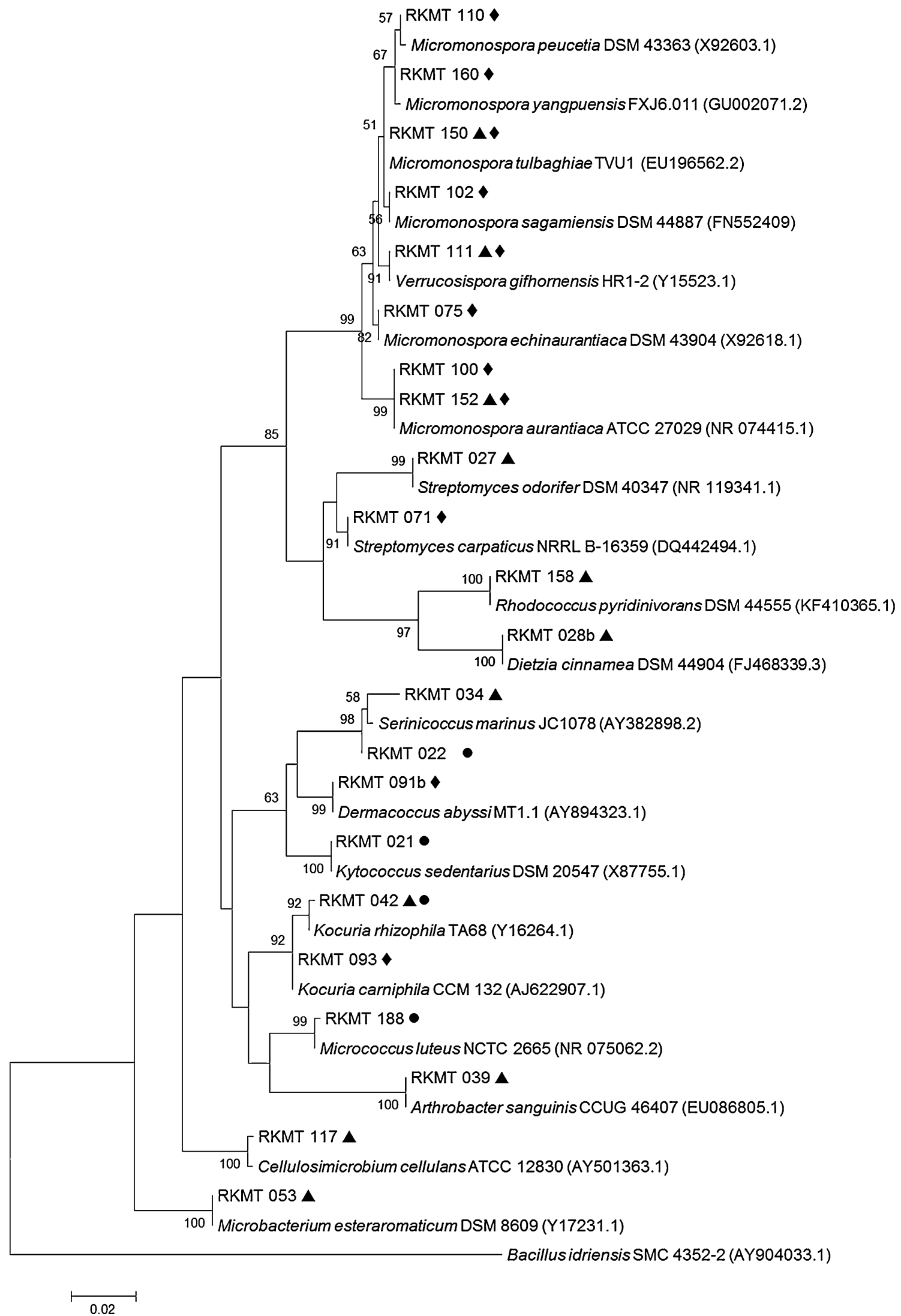


4Fig. 3 Phylogenetic analysis of Actinobacteria isolates obtained from Brazilian sediment and the invertebrates Luidia senegalensis and Olivancillaria urceus. Prior to tree construction, sequences sharing $>99 \%$ sequence identity were grouped into OTUs and a single representative of each OTU was used in the phylogenetic analysis. The sources of isolates belonging to an OTU are indicated by symbols which follow the strain number: wet sediment-square; dry sediment—diamond; Luidia senegalensis-triangle; Olivancillaria urceus_circle. Neighbor-joining tree constructed using MEGA 6. The analysis considered 621 nucleotides. Bootstrap values greater than $50 \%$ are shown at the nodes and are based on 1000 iterations. The scale bar represents the number of base substitutions per site

majority (39\%). Two Proteobacteria genera were recovered from $O$. urceus (Psychrobacter spp.-18\%, Pseudoalteromonas spp.-3\%), while the Actinobacteria isolates could be assigned to four genera (Kocuria-3\%, Serinicoccus-6\%, Kytococcus-6\% and Micrococcus-3\%).

Among all isolation media, media 4 and 5 were the most selective for Actinobacteria, as the greatest number of actinobacterial isolates (17) and genera (3) were recovered on these media (Tables 1 and S1). The greater selectivity for Actinobacteria corresponded to a lower recovery rate of Proteobacteria and Firmicutes on these media. Medium 3 yielded the fewest isolates (3), all of which were Firmicutes. The greatest number of isolates was obtained from Media 1 (20) and 2 (38); however, these media were less selective for Actinobacteria, as Firmicutes were primarily isolated from these media (41 isolates). MA also yielded a high number (45) of taxonomically different isolates and remarkably Actinobacteria were more abundant (21 isolates) than Firmicutes and Proteobacteria.

Evaluating the pretreatment methods utilized on the sediment sample, dispersal and differential centrifugation technique (DDC) was less productive than the dry-stamp method as it yielded only nine Proteobacteria strains belonging to two genera. The dry-stamp method was a better approach for the study of sediments, since it yielded a higher number of total isolates (41) and a greater variety of genera (10). In these experiments, the dry-stamp method was superior to the DDC technique for the isolation of Actinobacteria, as indicated by the isolation of Streptomyces (1 isolate),
Micromonospora (24 isolates) and Verrucosispora (2 isolates) strains, which are prolific sources of bioactive natural products as discussed previously. Among the methods used to isolate bacteria from the invertebrate samples, the heatshock method provided a higher total number of isolates (30) and greatest variety of genera (14). The heat-shock approach also resulted in the isolation of the greatest number of Actinobacteria isolates (10), which were identified as Micromonospora spp. (4), Kytococcus sp. (1), Cellulosimicrobium spp. (2), Micrococcus sp. (1) and Rhodococcus spp. (2). The phenol method resulted in the preferential isolation of Firmicutes (14 isolates) compared to Actinobacteria (2 isolates) and Proteobacteria (0 isolates). Plating the untreated invertebrate homogenate on MA resulted in the isolation of the greatest number of Actinobacteria strains (18) with the greatest taxonomic variety ( 8 genera) (Tables 1 and S1). Other than a single Streptomyces isolate, this non-selective approach yielded amycelial taxa belonging to the orders Micrococcales and Corynebacteriales. Not surprisingly, this approach also yielded the highest numbers of Firmicutes and Proteobacteria. Overall, heat-shock and phenol pretreatments selected for the isolation of Gram-positive bacteria (Firmicutes and Actinobacteria), as no Proteobacteria (Gram-negative) were obtained using these pretreatments (Table 1).

\section{Phylogenetic analysis}

All strains cultivated from the sediment sample and the two invertebrates were closely related to previously cultivated bacteria. In all cases, the 16S rRNA gene sequences of the isolated bacteria shared $>99 \%$ sequence similarity with cultured type strains (Table S1). The phylogenetic relationships of bacteria isolated in this study and selected type strains are shown in Figs. 1, 2 and 3. In general, each of the three samples examined in this study yielded a taxonomically distinct set of bacterial isolates, as evidenced by the small number of OTUs (8) formed by isolates obtained from more than one sample (Figs. 1, 2, and 3; isolates with more than one symbol following the strain number of the OTU representative).
Table 2 Antimicrobial activity of fermentation extracts derived from four strains

\begin{tabular}{lll}
\hline Marine isolate & Pathogen & \\
\cline { 2 - 3 } & S. aureus ATCC 33591 (MRSA) & S. warneri ATCC 17917 \\
\hline RKMT_178 (Bacillus sp.) & + & - \\
RKMT_160 (Micromonospora sp.) & ++ & - \\
RKMT_184 (Halobacillus sp.) & - & + \\
RKMT_071 (Streptomyces sp.) & - & ++ \\
\hline
\end{tabular}

No activity was observed against the other four pathogens (E. faecium, P. aeruginosa, P. vulgaris and $C$. albicans). No antimicrobial activity was observed in extracts from other strains examined Labels: - , no activity;,$+ 60<80 \%$ growth inhibition;,$++>80 \%$ growth inhibition 


\section{Antimicrobial assay}

To screen isolates for their ability to produce antimicrobial substances, all isolates $(n=134)$ were cultivated in marine broth and the fermentation extracts tested for antimicrobial activity against six pathogens. No activity was observed against the Gram-negative pathogens (P. aeruginosa, $P$. vulgaris) or $C$. albicans. Extracts from four strains inhibited the growth of the Staphylococcus spp. Two Actinobacteria (Streptomyces sp. and Micromonospora sp.) exhibited strong activity ( $>80 \%$ growth inhibition) against $S$. warneri and MRSA. The other two isolates exhibiting antimicrobial activity were Firmicutes (Bacillus sp. and Halobacillus sp.) and showed activity between 60 and $80 \%$ growth inhibition (Table 2).

\section{Chemical analysis of bioactive extracts}

To identify metabolites potentially responsible for the observed antimicrobial activity, extracts were analyzed by UPLC-HRMS-ELSD-PDA. Peaks with high intensity in the ELSD and/or HRMS chromatograms were selected for further examination as these abundant compounds would be the most likely components of the extract responsible for the observed bioactivity. The mass spectra were analyzed to identify the pseudomolecular ions corresponding to each peak. In all cases, two or more pseudomolecular ions $\left([\mathrm{M}+\mathrm{H}]^{+},\left[\mathrm{M}+\mathrm{NH}_{4}\right]^{+},[\mathrm{M}+\mathrm{Na}]^{+}\right)$were observed. To putatively identify these compounds, the molecular weights of observed pseudomolecular ions were used to search bacterial metabolites contained in the Antibase database

Table 3 Summary of metabolites observed in UPLC-HRMS analyses of fermentation extracts from four strains

\begin{tabular}{|c|c|c|c|c|c|c|}
\hline Strain ID & $t_{\mathrm{R}}(\min )$ & $\mathrm{PM}$ ion & $m / z$ & Molecular formula & Mass error (ppm) & Compound \\
\hline \multirow[t]{9}{*}{ RKMT_071 Streptomyces sp. } & \multirow[t]{2}{*}{3.06} & {$[\mathrm{M}+\mathrm{H}]^{+}$} & 560.3180 & \multirow[t]{2}{*}{ No hits } & \multirow[t]{2}{*}{-} & \multirow[t]{2}{*}{ Putatively new } \\
\hline & & {$[\mathrm{M}+\mathrm{Na}]^{+}$} & 582.3002 & & & \\
\hline & \multirow[t]{2}{*}{4.69} & {$[\mathrm{M}+\mathrm{H}]^{+}$} & 479.2907 & \multirow[t]{2}{*}{$\mathrm{C}_{29} \mathrm{H}_{38} \mathrm{~N}_{2} \mathrm{O}_{4}$} & \multirow[t]{2}{*}{0.75} & \multirow[t]{2}{*}{ Ikarugamycin } \\
\hline & & {$[\mathrm{M}+\mathrm{Na}]^{+}$} & 501.2729 & & & \\
\hline & \multirow[t]{3}{*}{6.83} & {$[\mathrm{M}+\mathrm{H}]^{+}$} & 1111.6448 & \multirow[t]{3}{*}{$\mathrm{C}_{54} \mathrm{H}_{90} \mathrm{~N}_{6} \mathrm{O}_{18}$} & \multirow[t]{3}{*}{5.48} & \multirow[t]{3}{*}{ Valinomycin } \\
\hline & & {$\left[\mathrm{M}+\mathrm{NH}_{4}\right]^{+}$} & 1128.6685 & & & \\
\hline & & {$[\mathrm{M}+\mathrm{Na}]^{+}$} & 1133.6243 & & & \\
\hline & \multirow[t]{2}{*}{7.55} & {$\left[\mathrm{M}+\mathrm{NH}_{4}\right]^{+}$} & 1142.6852 & \multirow[t]{2}{*}{ No hits } & \multirow[t]{2}{*}{-} & \multirow[t]{2}{*}{ Putatively new } \\
\hline & & {$[\mathrm{M}+\mathrm{Na}]^{+}$} & 1147.6389 & & & \\
\hline \multirow{4}{*}{$\begin{array}{l}\text { RKMT_160 Micromonospora } \\
\text { sp. }\end{array}$} & \multirow[t]{2}{*}{1.77} & {$[\mathrm{M}+\mathrm{H}]^{+}$} & 261.1233 & \multirow[t]{2}{*}{$\mathrm{C}_{14} \mathrm{H}_{16} \mathrm{~N}_{2} \mathrm{O}_{3}$} & \multirow[t]{2}{*}{0.10} & \multirow[t]{2}{*}{ cis-Cyclo(tyrosylprolyl) } \\
\hline & & {$[\mathrm{M}+\mathrm{Na}]^{+}$} & 283.1054 & & & \\
\hline & \multirow[t]{2}{*}{2.19} & {$[\mathrm{M}+\mathrm{H}]^{+}$} & 284.1393 & \multirow[t]{2}{*}{$\mathrm{C}_{16} \mathrm{H}_{17} \mathrm{~N}_{3} \mathrm{O}_{2}$} & \multirow[t]{2}{*}{0.14} & \multirow[t]{2}{*}{$\begin{array}{l}\text { Tryptophan-dehydrobutyrine } \\
\text { diketopiperazine }\end{array}$} \\
\hline & & {$[\mathrm{M}+\mathrm{Na}]^{+}$} & 306.1213 & & & \\
\hline \multirow[t]{4}{*}{ RKMT_178 Bacillus sp. } & \multirow[t]{2}{*}{2.52} & {$[\mathrm{M}+\mathrm{H}]^{+}$} & 345.1844 & \multirow[t]{2}{*}{ No hits } & \multirow[t]{2}{*}{-} & \multirow[t]{2}{*}{ Putatively new } \\
\hline & & {$[\mathrm{M}+\mathrm{Na}]^{+}$} & 363.1948 & & & \\
\hline & 2.54 & {$[\mathrm{M}+\mathrm{H}]^{+}$} & 389.1915 & No hits & - & Putatively new \\
\hline & & {$[\mathrm{M}+\mathrm{Na}]^{+}$} & 411.1732 & & & \\
\hline RKMT_184 Halobacillus sp. & 1.97 & {$[\mathrm{M}+\mathrm{H}]^{+}$} & 316.1295 & $\mathrm{C}_{16} \mathrm{H}_{17} \mathrm{~N}_{3} \mathrm{O}_{4}$ & 0.09 & Anthramycin \\
\hline & & {$[\mathrm{M}+\mathrm{Na}]^{+}$} & 338.1109 & & & \\
\hline & 2.07 & {$[\mathrm{M}+\mathrm{H}]^{+}$} & 351.1213 & $\mathrm{C}_{21} \mathrm{H}_{18} \mathrm{O}_{5}$ & 4.04 & Brasiliquinone-C \\
\hline & & {$[\mathrm{M}+\mathrm{Na}]^{+}$} & 373.1032 & & & \\
\hline & 2.07 & {$[\mathrm{M}+\mathrm{H}]^{+}$} & 325.1249 & No hits & - & Putatively new \\
\hline & & {$[\mathrm{M}+\mathrm{Na}]^{+}$} & 347.1070 & & & \\
\hline & 2.13 & {$[\mathrm{M}+\mathrm{H}]^{+}$} & 217.0972 & $\mathrm{C}_{12} \mathrm{H}_{12} \mathrm{~N}_{2} \mathrm{O}_{2}$ & 0.54 & Four possible compounds \\
\hline & & {$[\mathrm{M}+\mathrm{Na}]^{+}$} & 239.0802 & & & \\
\hline & 2.28 & {$[\mathrm{M}+\mathrm{H}]+$} & 349.1791 & No hits & - & Putatively new \\
\hline & & {$[\mathrm{M}+\mathrm{Na}]^{+}$} & 371.1613 & & & \\
\hline & 2.26 & {$[\mathrm{M}+\mathrm{H}]^{+}$} & 375.1754 & No hits & - & Putatively new \\
\hline & & {$[\mathrm{M}+\mathrm{Na}]^{+}$} & 397.1574 & & & \\
\hline
\end{tabular}

To identify metabolites detected in these analyses, the pseudomolecular (PM) ion $m / z$ was used to search the Antibase 2014 database using a 5 ppm window above and below the observed molecular weight (MW). A $10 \mathrm{ppm}$ search window was used for pseudomolecular ions with $\mathrm{m} / z$ $>1000$. Compounds with no matches in Antibase were considered putatively novel 
(Wiley ${ }^{\circledR}$, 2014). Streptomyces sp. RKMT_071 produced four major compounds, which eluted at 3.06, 4.69, 6.83 and $7.55 \mathrm{~min}$ (Figure S1). The peak at $5.40 \mathrm{~min}$ in the ELSD trace corresponds to compounds that do not ionize in the positive mode in the mass spectrometry analysis. This fact and the high retention time suggest it corresponds to fatty acids already reported for bacteria (O'leary 1962). The compounds eluting at $3.06 \mathrm{~min}\left(\mathrm{~m} / z 560.3180[\mathrm{M}+\mathrm{H}]^{+}\right)$and $7.55 \mathrm{~min}\left(\mathrm{~m} / \mathrm{z} 1147.6389[\mathrm{M}+\mathrm{Na}]^{+}\right)$had no hits within $5 \mathrm{ppm}$ in the Antibase 2014 database, suggesting that these compounds may be novel metabolites. The compound eluting at $4.69 \mathrm{~min}$ with a $\mathrm{m} / \mathrm{z}$ of $479.2907[\mathrm{M}+\mathrm{H}]^{+}$had four hits in Antibase with theoretical $[\mathrm{M}+\mathrm{H}]^{+}$masses $<5$ ppm from the observed mass (actual deviation $0.75 \mathrm{ppm}$ ). All compounds had the molecular formula $\mathrm{C}_{29} \mathrm{H}_{38} \mathrm{~N}_{2} \mathrm{O}_{4}$ and corresponded to the known Streptomyces metabolites ikarugamycin (Jomon et al. 1972), and three acylated phenazines (sapienic acid myristoyl ester, tetradecanoic acid saphenyl ester, and 12-methyltridecanoic acid saphenyl ester) (Laursen and Nielsen 2004). The same ion was detected in the PDA detector and presented two maximal peaks at 227 and $327 \mathrm{~nm}$ (Figure S2). Phenazines show a UV absorption at 250 and $360 \mathrm{~nm}$ (Mehnaz et al. 2009) and ikarugamycin a UV absorption of 220 and $325 \mathrm{~nm}$ (Jomon et al. 1972). Therefore, the compound detected is most likely ikarugamycin. The compound eluting at $6.83 \mathrm{~min}$ corresponded to a compound with a $\mathrm{m} / z 1111.6448[\mathrm{M}+\mathrm{H}]^{+}$. Due to the large size of this molecule, the search window was broadened to $10 \mathrm{ppm}$ and resulted in a single hit corresponding to valinomycin $\left(\Delta_{\mathrm{ppm}}=5.48\right)(\mathrm{Li}$ et al. 2015). The extract from Micromonospora sp. RKMT_160 contained two major metabolites (Figure S3). The compound eluting at $1.77 \mathrm{~min}$ with a $\mathrm{m} / z 261.1233[\mathrm{M}+\mathrm{H}]^{+}$matched four previously reported compounds in Antibase with $[\mathrm{M}+\mathrm{H}]^{+}$molecular formulae corresponding to $\mathrm{C}_{14} \mathrm{H}_{16} \mathrm{~N}_{2} \mathrm{O}_{3}\left(\Delta_{\text {ppm }}=0.10\right)$. These compounds were cyclo(Tyr-Pro), previously reported from Aspergillus flavipes and Streptomyces sp. strains (Barrow and Sun 1994; Wattana-Amorn et al. 2015), and cyclo(Phe-4-hydroxyPro), reported from Aureobasidium pullulans and unclassified marine bacteria strains (Shigemori et al. 1998; Fdhila et al. 2003), both diketopiperazines with varying stereochemical configurations. The compound eluting at 2.19 min with a $m / z 284.1393[\mathrm{M}+\mathrm{H}]^{+}$ matched a single entry in Antibase, tryptophan-dehydrobutyrine diketopiperazine $\left(\Delta_{\mathrm{ppm}}=0.14\right)$ (Kakinuma et al. 1974). The diketopiperazines with masses matching those of the compounds in the RKMT_160 extracts were all previously reported from Streptomyces.

Study of the extract from strain RKMT_178 showed no known compounds produced by this isolate with two major compounds with retention times at $2.52 \mathrm{~min}$ and $2.54 \mathrm{~min}$ (Figure S4).
Halobacillus sp. RKMT_184 produced six major compounds (Figure S5) which eluted at 1.97, $2.07 \mathrm{~min}$ (two compounds), 2.13, 2.26 and $2.28 \mathrm{~min}$. The peaks at 5.10 and $5.57 \mathrm{~min}$ in the ELSD trace likely correspond to fatty acids as these compounds did not ionize in positive mode in the HRMS analysis and eluted late in the chromatogram, indicating that the compounds were highly nonpolar (O'leary 1962). The compounds eluting at $2.28 \mathrm{~min}(\mathrm{~m} / \mathrm{z}$ $\left.349.1791[\mathrm{M}+\mathrm{H}]^{+}\right), 2.26 \min \left(\mathrm{m} / z 375.1754[\mathrm{M}+\mathrm{H}]^{+}\right)$ and $2.07 \mathrm{~min}\left(\mathrm{~m} / \mathrm{z} 325.1249[\mathrm{M}+\mathrm{H}]^{+}\right)$had no hits within $5 \mathrm{ppm}$ in the Antibase 2014 database, suggesting that these compounds may be novel metabolites. The compound eluting at $1.97 \mathrm{~min}$ with a $\mathrm{m} / z$ of $316.1295[\mathrm{M}+\mathrm{H}]^{+}$had two hits in Antibase with the molecular formula $\mathrm{C}_{16} \mathrm{H}_{17} \mathrm{~N}_{3} \mathrm{O}_{4}$ $\left(\Delta_{\mathrm{ppm}}=0.09 \mathrm{ppm}\right)$. The compounds corresponded to the known Streptomyces metabolites anthramycin and maremycin. Due to the antimicrobial activity of the RKMT_184 extract, the detected compound is most likely anthramycin, as this compound has reported antibiotic activity (Kohn et al. 1967). The compound eluting at $2.07 \mathrm{~min}$ with a $\mathrm{m} / z 351.1213[\mathrm{M}+\mathrm{H}]^{+}$had six hits in Antibase with the molecular formula $\mathrm{C}_{21} \mathrm{H}_{18} \mathrm{O}_{5}\left(\Delta_{\mathrm{ppm}}=4.04 \mathrm{ppm}\right)$. However, only one of them, brasiliquinone $\mathrm{C}$, was reported from a bacterial source. Brasilquinone $\mathrm{C}$ is active against Gram-positive bacteria and thus may be in part responsible for the antimicrobial activity observed in the RKMT_184 extract (Nemoto et al. 1997). The compound eluting at $2.13 \mathrm{~min}$ with a $\mathrm{m} / \mathrm{z}$ of $217.0972[\mathrm{M}+\mathrm{H}]^{+}$had four hits in Antibase with the molecular formula $\mathrm{C}_{12} \mathrm{H}_{12} \mathrm{~N}_{2} \mathrm{O}_{2}$ $\left(\Delta_{\mathrm{ppm}}=0.54 \mathrm{ppm}\right)$, which is consistent with the known actinomycete metabolites $\mathrm{N}$-acetyl- $\beta$-oxotryptamine, mansouramycin A, sannanine and caerulomycin F. Since all were previously reported as produced by bacterial sources, no specific compound can be attributed to the ion detected. All the extracted chromatograms are shown in Figure S6. A summary of the ions detected in bioactive extract is provided in Table 3.

\section{Discussion}

The emergence of so-called superbacteria is a serious health concern as nosocomial infections by MRSA, as one example, are responsible for 19,000 deaths per year in the USA. These pathogens are resistant to $\beta$-lactam antibiotics (e.g., penicillins, cephalosporins, carbapenens), which are an important class of broad-spectrum antimicrobial agents, comprising more than $65 \%$ of the world antibiotic market (Poole 2004). Thus, the discovery of new antibiotics efficacious against drug-resistant pathogens is critically important. As the majority of antibiotics are derived from microorganisms, screening new microorganisms for novel 
antibiotics is of utmost importance for the discovery of more effective drugs.

Brazil hosts approximately $20 \%$ of the entire world's macro-organism biological diversity (Pylro et al. 2014). Despite its geographic size, Brazilian marine microbial diversity is still underexplored (Berlinck et al. 2004). In order to improve knowledge regarding the biotechnological potential of the Brazilian biodiversity, we investigated the cultivable bacteria associated with two marine invertebrates and a sediment sample collected from the Ubatuba region of the Brazilian coast and tested the ability of these bacteria to produce antimicrobial agents.

Comparison of these three sources showed that the sea star yielded the highest number of bacterial isolates and greatest variety of genera, including isolates from Micromonospora, Streptomyces and rare genera such as Serinicoccus and Verrucosispora (Yang et al. 2013; YiLei et al. 2014). The sediment provided the second highest number of isolates and variety of genera, including Micromonospora, Streptomyces and Verrucosispora. The lowest number of isolates and genera was obtained from O. urceus. However, rare bacteria such as Serinicoccus sp. were isolated from this source. These genera, together with Streptomyces, are actinomycetes with a proven ability to produce bioactive metabolites (Solanki et al. 2008). These results show the potential of by-catch invertebrates as a source of a wide diversity of bacterial genera with biotechnological potential.

Of the isolation media employed in this study, media 4 and 5 exhibited the greatest selectivity for the isolation of Actinobacteria. This may be due to the low nutrient concentration of these media, thereby reducing the growth of non-actinomycete bacteria and preventing the overgrowth of actinomycetes (Jensen et al. 2005). The selectivity for actinomycetes can also be attributed to the use of novobiocin in these media, since it suppresses the growth of Gram-positive bacteria (Dalisay et al. 2013), such as Firmicutes, which were abundant on other media. Marine agar (MA) was also a good medium for the isolation of Actinobacteria, although this non-selective medium favored the cultivation of primarily non-filamentous Actinobacteria. The paucity of filamentous bacteria isolated on non-selective media indicates that filamentous actinomycetes are relatively rare in the samples examined in this study, thus necessitating the application of selective isolation media to increase the frequency of isolating these bacteria. The fewest isolates were obtained from media 3, which was supplemented with rifampicin and streptomycin to select for the cultivation of rare actinomycetes. The low yield of isolates from this media suggests that the combination of antibiotics inhibited the vast majority of bacteria present in the three samples studied (Pankey and Sabath 2004; BakkerWoudenberg et al. 2005).
Two different sets of pretreatments were applied to the sediment and invertebrate samples. The dry-stamp method was superior to the DDC pretreatment both in terms of diversity of genera obtained and selectivity for actinomycetes. Drying the sediments combined with the use of selective media selected against the isolation of Gramnegative bacteria, which are abundant in marine habitats, and clearly favored the growth of Gram-positive bacteria (Gontang et al. 2007). The DDC method yielded very few isolates overall and no Actinobacteria despite this approach being successfully applied for the isolation of actinomycetes from soil when coupled with selective isolation media (Semêdo et al. 2001). This may be explained by the fact that the method is not selective for Actinobacteria and allows for the growth of fast-growing Proteobacteria that overgrew Actinobacteria present in the sample. The low productivity of the DDC method could also be due to the use of deionized water with a marine sediment. The use of deionized water, rather than sea water, may have caused osmotic stress, resulting in reduced viability of marine bacteria present in the sediment. The heat-shock method was clearly the most productive pretreatment applied to the invertebrate samples. This approach has been reported to control the over growth of non-actinomycete colonies on isolation plates (Varghese et al. 2015). In our study, the heat-shock method reduced the growth of unwanted bacteria and allowed the unfettered growth of more interesting isolates. Pretreatment with $1.5 \%$ phenol has been used for the isolation of sporogenous taxa and members of the less abundant Streptomyces spp. (Hayakawa et al. 2004). The low number of isolates obtained using the phenol pretreatment may be due to a low abundance of sporulating taxa in these samples. Untreated samples were a good source for the isolation of bacteria in general, but with no selectivity as Actinobacteria, Proteobacteria and Firmicutes were isolated. The high proportion of Actinobacteria isolated from untreated samples may be attributed to the wide dilution performed, which allowed actinomycetes to avoid over growth.

Screening 134 isolates for antimicrobial activity identified four strains that produced antimicrobial substances active against staphylococci. The relatively low hit rate observed among these isolates is likely due to the use of a single fermentation medium, as the production of secondary metabolites is highly dependent on media composition (Bode et al. 2002). Further exploration of the metabolomes of the strains isolated in this study using a wider array of fermentation conditions would undoubtedly uncover additional bioactivity.

The observed bioactivity was limited to four isolates: two Firmicutes (Bacillus and Halobacillus) and two Actinobacteria (Micromonospora and Streptomyces). Bacillus spp. are well known for their ability to produce 
antimicrobial lipopeptides such as gramicidin A, which is active against $S$. aureus (Liou et al. 2015). Interestingly, no known lipopeptides were identified in the fermentation extracts of RKMT_178 and RKMT_184; however, several low molecular weight compounds were detected in UPLCHRMS analyses of fermentation extracts from these strains. Compounds anthramycin and brasiliquinone-C were identified in the extract from RKMT_184. Both compounds are reported as antimicrobial agents and may be responsible for the antimicrobial activity exhibited by the fermentation extract of this strain (Kohn et al. 1967; Nemoto et al. 1997). N-acetyl- $\beta$-oxotryptamine, mansouramycin A, sannanine and caerulomycin $\mathrm{F}$ were also tentatively identified, although further study is needed to confirm the identity of the active constituents of these extracts. The other compounds did not correspond to known metabolites present in Antibase 2014. Consequently, one or more of the metabolites produced by these strains may represent novel antimicrobial metabolites. Additionally, it should be noted that these strains were isolated form $O$. urceus and L. senegalensis, underscoring the biomedical potential of microbes obtained from by-catch organisms.

Actinobacteria such as Micromonospora spp. are sources of antibiotics such as aminoglycosides, macrolides and ansamycins (Wagman and Weinstein 1980). The antimicrobial activity observed in fermentation extracts of RKMT_160 can be tentatively associated with the presence of the diketopiperazines cis-cyclo(tyrosylprolyl) and tryptophan-dehydrobutyrine diketopiperazine, previously reported for Streptomyces spp. with antimicrobial activity (Kakinuma et al. 1974; Elleuch et al. 2010). The occurrence of the same secondary metabolites in both Streptomyces spp. and Micromonospora spp. has been reported previously (Wagman and Weinstein 1980). Production of diketopiperazines by Micromonospora spp. has also been reported (Yang et al. 2004).

Streptomycetes are the most studied Actinobacteria and are known for the production of a wide diversity of active secondary metabolites such as antibiotics, antivirals, antitumoral, and immunosuppressives. The presence of the potent antibiotic ikarugamycin, previously reported from Streptomyces spp. (Jomon et al. 1972; Li et al. 2015), is likely responsible for the high antimicrobial activity observed for Streptomyces sp. RKMT_071.

\section{Conclusion}

A great variety of bacterial genera were cultured from two invertebrates, $O$. urceus and $L$. senegalensis, and a single sediment sample collected in the region of the city of Ubatuba. This study underscores the great potential to discover an even greater diversity of marine bacteria through the systematic exploration of the marine habitats present in Brazil's extensive coastal areas. A lack of publications regarding the marine bacteria and associated natural products from Brazilian waters indicates that this resource is highly underexplored. The variety and abundance of the bacteria associated with marine invertebrates from the by-catch and sediment collected in the Brazilian southeast coast have proved that this habitat can be an important source of bioactive natural products. Also, the study showed how by-catch can be a good source of bacteria with biotechnological potential. Additional studies will be performed to isolate and characterize the bioactive compounds responsible for the antimicrobial activity observed. Also, fermentation in multiple media of the taxa with high biosynthetic potential may also provide new and active natural products.

Acknowledgments The authors thank the São Paulo State Research Foundation (FAPESP) for funding and fellowships (Grant 2012/19419-9 to W.V. and Grants 2011/23159-0 and 2014/08787-0 to M.M.P.T.) The UPEI authors gratefully acknowledge financial support from the Natural Sciences and Engineering Council of Canada, the Canada Research Chair Program, the Atlantic Canada Opportunities Agency, Canada Foundation for Innovation, Nautilus Biosciences Canada Inc. and the Jeanne and Jean-Louis Lévesque Foundation.

Conflict of Interest The authors declare that they have no conflict of interest.

\section{References}

Altschul SF, Gish W, Pennsylvania T, Park U (1990) Basic local alignment search tool. J Mol Biol 215:403-410. doi:10.1016/ S0022-2836(05)80360-2

Athalye M, Lacey J, Goodfellow M (1981) Selective isolation and enumeration of actinomycetes using rifampicin. J Appl Bacteriol 51:289-297. doi:10.1111/j.1365-2672.1981.tb01244.x

Bakker-Woudenberg IAJM, van Vianen W, van Soolingen D et al (2005) Antimycobacterial agents differ with respect to their bacteriostatic versus bactericidal activities in relation to time of exposure, mycobacterial growth phase, and their use in combination. Antimicrob Agents Chemother 49:2387-2398. doi:10.1128/ AAC.49.6.2387-2398.2005

Barrow CJ, Sun HH (1994) Spiroquinazoline, a novel substance-P inhibitor with a new carbon skeleton, isolated from Aspergillus flavipes. J Nat Prod 57:471-476. doi:10.1021/np50106a005

Berlinck RGS, Hajdu E, da Rocha RM et al (2004) Challenges and rewards of research in marine natural products chemistry in Brazil. J Nat Prod 67:510-522. doi:10.1021/np0304316

Bister B, Bischoff D, Ströbele M et al (2004) Abyssomicin C-a polycyclic antibiotic from a marine Verrucosispora strain as an inhibitor of the p-aminobenzoic acid/tetrahydrofolate biosynthesis pathway. Angew Chemie Int Ed 43:2574-2576. doi:10.1002/ anie. 200353160

Blunt JW, Copp BR, Keyzers RA et al (2015) Marine natural products. Nat Prod Rep 32:116-211. doi:10.1039/C4NP00144C

Bode HB, Bethe B, Höfs R, Zeeck A (2002) Big effects from small changes: possible ways to explore nature's chemical diversity. ChemBioChem 3:619. doi:10.1002/14397633(20020703)3:7<619:AID-CBIC619>3.0.CO;2-9 
Clarck AM, Downey ME (1992) Starfishes of the Atlantic. Chapman \& Hall Identification Guides 3. Chapman \& Hall Identification Guides, London

Dalisay DS, Williams DE, Wang XL et al (2013) Marine sedimentderived Streptomyces bacteria from British Columbia, Canada are a promising microbiota resource for the discovery of antimicrobial natural products. PLoS One 8:1-15. doi:10.1371/journal. pone.0077078

de Procópio RE, da Silva IR, Martins MK et al (2012) Antibiotics produced by Streptomyces. Braz J Infect Dis 16:466-471. doi:10.1016/j.bjid.2012.08.014

Dos Santos JL (2007) Pesca e Estrutura Populacional do camarãobranco Litopenaeus schmitti (Burkenroad, 1936) na região marinha e estuarina da baixada santista, São Paulo, Brasil

Duncan K, Haltli B, Gill K, Kerr RG (2014) Bioprospecting from marine sediments of New Brunswick, Canada: exploring the relationship between total bacterial diversity and actinobacteria diversity. Mar Drugs 12:899-925. doi:10.3390/md12020899

Dworkin M, Falkow S, Rosenberg E et al (2006) The prokaryotes-volume 3: Archaea. Bacteria: firmicutes, actinomycetes. Springer, New York

Eayrs S (2007) A guide to bycatch reduction in tropical shrimp-trawl fisheries, Revis edn. FAO, Rome, p 108

Edwards U, Rogall T, Blöcker H et al (1989) Isolation and direct complete nucleotide determination of entire genes. Characterization of a gene coding for $16 \mathrm{~S}$ ribosomal RNA. Nucleic Acids Res 17:7843-7853. doi:10.1093/nar/17.19.7843

El Amraoui B, El Amraoui M, Cohen N, Fassouane A (2014) Antifungal and antibacterial activity of marine microorganisms. Ann Pharm françaises 72:107-111. doi:10.1016/j. pharma.2013.12.001

Elleuch L, Shaaban M, Smaoui S et al (2010) Bioactive secondary metabolites from a new terrestrial streptomyces sp. TN262. Appl Biochem Biotechnol 162:579-593. doi:10.1007/ s12010-009-8808-4

Fdhila F, Vazquez V, Sánchez JL, Riguera R (2003) DD-Diketopiperazines: antibiotics active against Vibrio anguillarum isolated from marine bacteria associated with cultures of Pecten maximus. $\mathbf{J}$ Nat Prod 66:1299-1301. doi:10.1021/np030233e

Felsenstein J (1985) Confidence limits on phylogenies: an approach using the bootstrap. Evolution (NY) 39:783. doi: $10.2307 / 2408678$

Fischbach MA, Walsh CT (2009) Antibiotics for emerging pathogens. Science 325:1089-1093. doi:10.1126/science.1176667

Gontang EA, Fenical W, Jensen PR (2007) Phylogenetic diversity of gram-positive bacteria cultured from marine sediments. Appl Environ Microbiol 73:3272-3282. doi:10.1128/AEM.02811-06

Graça Lopes R, Tomás ARG, Tutui SLS et al (2002) Fauna acompanhante da pesca camaroeira no litoral do estado de São Paulo, brasil*. Bol do Inst Pesca 28:173-188

Hayakawa M, Nonomura H (1987) Humic acid-vitamin agar, a new medium for the selective isolation of soil actinomycetes. J Ferment Technol 65:501-509. doi:10.1016/0385-6380(87)90108-7

Hayakawa M, Yoshida Y, Iimura Y (2004) Selective isolation of bioactive soil actinomycetes belonging to the Streptomyces violaceusniger phenotypic cluster. J Appl Microbiol 96:973-981. doi:10.1111/j.1365-2672.2004.02230.x

Haygood MG, Schmidt EW, Davidson SK, Faulkner DJ (1999) Microbial symbionts of marine invertebrates: opportunities for microbial biotechnology. J Mol Microbiol Biotechnol 1:33-43

Hong K, Gao AH, Xie QY et al (2009) Actinomycetes for marine drug discovery isolated from mangrove soils and plants in China. Mar Drugs 7:24-44. doi:10.3390/md7010024

Hopkins DW, Macnaughton SJ, O’Donnell AG (1991) A dispersion and differential centrifugation technique for representatively sampling microorganisms from soil. Soil Biol Biochem 23:217225. doi:10.1016/0038-0717(91)90055-O

Ióca LP, Allard P-M, Berlinck RGS (2014) Thinking big about small beings-the (yet) underdeveloped microbial natural products chemistry in Brazil. Nat Prod Rep 31:646-675. doi:10.1039/ c3np70112c

Jensen PR, Gontang E, Mafnas C et al (2005) Culturable marine actinomycete diversity from tropical Pacific Ocean sediments. Environ Microbiol 7:1039-1048. doi:10.1111/j.1462-2920.2005.00785.x

Jomon K, Kuroda Y, Ajisaka M, Heiichi S (1972) A new Antibiotic, Ikarugamycin. J Antibiot (Tokyo) 25:271-280. doi:10.7164/ antibiotics.25.271

Kakinuma K, Kenneth L, Rinehart J (1974) Tryptophan-dehydrobutyrine diketopiperazine, a metabolite of Streptomyces spectabilis. J Antibiot (Tokyo) XXVII:733-737. doi:10.1017/ CBO9781107415324.004

Kim BY, Kshetrimayum JD, Goodfellow M (2011) Detection, selective isolation and characterisation of Dactylosporangium strains from diverse environmental samples. Syst Appl Microbiol 34:606-616. doi:10.1016/j.syapm.2011.03.008

Kim M, Oh H-S, Park S-C, Chun J (2014) Towards a taxonomic coherence between average nucleotide identity and 16S rRNA gene sequence similarity for species demarcation of prokaryotes. Int J Syst Evol Microbiol 64:346-351. doi:10.1099/ ijs.0.059774-0

Kohn KW, Bono VH, Kann HE (1967) Anthramycin, a new type of DNA-inhibiting antibiotic: reaction with DNA and effect on nucleic acid synthesis in mouse leukemia cells. Biochim Biophys Acta 155:121-129

Laursen JB, Nielsen J (2004) Phenazine natural products: biosynthesis, synthetic analogues, and biological activity. Chem Rev 104:1663-1685. doi:10.1021/cr020473j

Li J, Jaitzig J, Lu P et al (2015) Scale-up bioprocess development for production of the antibiotic valinomycin in Escherichia coli based on consistent fed-batch cultivations. Microb Cell Fact 14:83. doi:10.1186/s12934-015-0272-y

Liou J-W, Hung Y-J, Yang C-H, Chen Y-C (2015) The antimicrobial activity of gramicidin a is associated with hydroxyl radical formation. PLoS One 10:e0117065. doi:10.1371/journal. pone. 0117065

Mehnaz S, Baig DN, Jamil F et al (2009) Characterization of a phenazine and hexanoyl homoserine lactone producing Pseudomonas aurantiaca strain PB-St2, isolated from sugarcane stem. J Microbiol Biotechnol 19:1688-1694. doi:10.4014/jmb.0904.04022

Mincer TJ, Jensen PR, Kauffman CA, Fenical W (2002) Widespread and persistent populations of a major new marine actinomycete taxon in ocean sediments. Appl Environ Microbiol 68:50055011. doi:10.1128/AEM.68.10.5005

Nemoto A, Tanaka Y, Karasaki Y et al (1997) Brasiliquinones A, B and $\mathrm{C}$, New Benz[a]anthraquinone Antibiotics from Nocardia brasiliensis-I. Producing strain, isolation and biological activities of the antibiotics. J Antibiot (Tokyo) 50:18-21. doi:10.7164/ antibiotics.50.18

Niewerth D, Jansen G, Riethoff LFV et al (2014) Antileukemic activity and mechanism of drug resistance to the marine Salinispora tropica proteasome inhibitor salinosporamide A (Marizomib). Mol Pharmacol 86:12-19. doi:10.1124/mol.114.092114

O'leary WM (1962) The fatty acids of bacteria. Bacteriol Rev 26:421-447

Pankey GA, Sabath LD (2004) Clinical relevance of bacteriostatic versus bactericidal mechanisms of action in the treatment of Gram-positive bacterial infections. Clin Infect Dis 38:864-870. doi: $10.1086 / 381972$

Poole K (2004) Resistance to $\beta$-lactam antibiotics. Cell Mol Life Sci 61:2200-2223. doi:10.1007/s00018-004-4060-9 
Pylro VS, Roesch LFW, Ortega JM et al (2014) Brazilian microbiome project: revealing the unexplored microbial diversity-challenges and prospects. Microb Ecol 67:237-241. doi:10.1007/ s00248-013-0302-4

Qiu D, Ruan J, Huang Y (2008) Selective isolation and rapid identification of members of the genus Micromonospora. Appl Environ Microbiol 74:5593-5597. doi:10.1128/AEM.00303-08

Röding PF (1798) Museum Boltenianum sive catalogus cimeliorum e tribus regnis naturae quae olim collegerat Joa. Fried. Bolten M. D. p. d. Pars secunda continens Conchylia sive Testacea univalvia, bivalvia et multivalvia. British Museum (Natural History), London

Rowbotham TJ, Cross T (1977) Rhodococcus coprophilus sp. nov.: an aerobic nocardioform actinomycete belonging to the "rhodochrous" complex. J Gen Microbiol 100:123-138. doi:10.1099/00221287-100-1-123

Saitou N, Nei M (1987) The neighbor-joining method: a new method for reconstructing phylogenetic trees. Mol Biol Evol 4:406-425

Semêdo LT, Linhares AA, Gomes RC et al (2001) Isolation and characterization of actinomycetes from Brazilian tropical soils. Microbiol Res 155:291-299. doi:10.1016/ S0944-5013(01)80007-0

Severino-rodrigues E, Hebling NJ, Graça-lopes R (2004) Biodiversidade no produto da pesca de arrasto-de-fundo dirigida ao lagostim, Metanephrops rubellus (Moreira, 1903), desembarcado no litoral do estado de São Paulo, Brasil. Bol do Inst Pesca 33:171-182

Shigemori H, Tenma M, Shimazaki K, Kobayashi J (1998) Three new metabolites from the marine yeast Aureobasidium pullulans. J Nat Prod 61:696-698. doi:10.1021/np980011u

Solanki R, Khanna M, Lal R (2008) Bioactive compounds from marine actinomycetes. Indian $\mathrm{J}$ Microbiol 48:410-431. doi:10.1007/s12088-008-0052-z

Spellberg B, Guidos R, Gilbert D et al (2008) The epidemic of antibiotic-resistant infections: a call to action for the medical community from the Infectious Diseases Society of America. Clin Infect Dis 46:155-164. doi:10.1086/524891
Sponga F, Cavaletti L, Lazzarini A et al (1999) Biodiversity and potentials of marine-derived microorganisms. Prog Ind Microbiol 35:65-69. doi:10.1016/S0079-6352(99)80099-X

Tamura K, Stecher G, Peterson D et al (2013) MEGA6: molecular evolutionary genetics analysis version 6.0. Mol Biol Evol 30:2725-2729. doi:10.1093/molbev/mst197

Varghese TA, Jayasri MA, Suthindhiran K (2015) Marine Actinomycetes as potential source for histone deacetylase inhibitors and epigenetic modulation. Lett Appl Microbiol 61:69-76. doi:10.1111/lam.12430

Vicente J, Stewart A, Song B et al (2013) Biodiversity of actinomycetes associated with Caribbean sponges and their potential for natural product discovery. Mar Biotechnol 15:413-424. doi:10.1007/s10126-013-9493-4

Wagman GH, Weinstein MJ (1980) Antibiotics from micromonospora. Annu Rev Microbiol 34:537-558. doi:10.1146/annurev. mi.34.100180.002541

Wattana-Amorn P, Charoenwongsa W, Williams C et al (2015) Antibacterial activity of cyclo(L-Pro-L-Tyr) and cyclo(D-Pro-L-Tyr) from Streptomyces sp. strain 22-4 against phytopathogenic bacteria. Nat Prod Res 6419:1-4. doi:10.1080/14786419.2015.1095 747

Williams ST, Davies FL (1965) Use of antibiotics for selective isolation and enumeration of actinomycetes in soil. J Gen Microbiol 38:251-261. doi:10.1099/00221287-38-2-251

Yang S-W, Chan T-M, Terracciano J et al (2004) Structure elucidation of a new diketopiperazine Sch 725418 from Micromonospora sp. J Antibiot (Tokyo) 57:345-347. doi:10.7164/antibiotics.57.345

Yang XW, Zhang GY, Ying JX et al (2013) Isolation, characterization, and bioactivity evaluation of 3-((6-methylpyrazin-2-yl)methyl)$1 \mathrm{H}$-indole, a new alkaloid from a deep-sea-derived actinomycete serinicoccus profundi sp. nov. Mar Drugs 11:33-39. doi: $10.3390 / \mathrm{md} 11010033$

Yi-Lei N, Yun-Dan W, Chuan-Xi W et al (2014) Compounds from marine-derived Verrucosispora sp. FIM06054 and their potential antitumour activities. Nat Prod Res 28:2134-2139. doi:10.1080/ 14786419.2014.926350 